\title{
PENINGKATAN KEMAMPUAN MEMBUAT KALIMAT TANYA MELALUI GAMES JEOPARDY SISWA KELAS V SDN NO.13 ALLU I KECAMATAN BANGKALA KABUPATEN JENEPONTO
}

\begin{abstract}
Abdul Talib
Abstrak

Penelitian ini bertujuan meningkatkan kemampuan membuat kalimat tanya siswa kelas V SDN No.13 Allu I Kecamatan Bangkala Kabupaten Jeneponto melalui penggunaan Model Games Jeopardy.Rancangan Penelitian yang digunakan adalah rancangan penelitian tindakan kelas. Prosedur pelaksanaan dalam penelitian ini melalui tahapan-tahapan yang meliputi : Studi pendahuluan, perencanaan, pelaksanaan tindakan, pengamatan, dan refleksi. Data penelitian berupa data proses dan hasil tindakan yang diperoleh dari hasil observasi, wawancara, catatan lapangan dokumentasi, dan rekaman. Hasil penelitian menunjukkan bahwa pada tes siklus I, 9 orang atau $36 \%$ siswa mendapat nilai $\leq 65$ dan 16 orang atau $64 \%$ masuk dalam kategori tuntas yaitu memperoleh nilai $\geq 65$. Pada tes siklus II, 4 orang atau $16 \%$ siswa mendapat nilai $\leq 65$ dan 21 orang atau $84 \%$ siswa masuk dalam kategori tuntas mendapat nilai $\geq 65$ penerapan model Jeopardy dapat meningkatkan frekwensi keaktifan dan aktivitas dalam proses belajar mengajar sesuai dengan pengamatan sikap siswa dalam pelaksanaan tindakan kelas pada siklus I dan siklus II. Untuk Peningkatkan kemampuan membuat kalimat tanya siswa, maka diharapkan guru dapat menerapkan model Games Jeopardy sebagai salah satu alternatif dalam pembelajaran bahasa Indonesia.
\end{abstract}

\section{Kata kunci:Peningkatan, kemampuan, kalimat tanya, Games Jeopardy}

\begin{abstract}
The objective of the study was to improve the ability of make Question Sentence By Jeopardy Games Students Of Grade V SDN No.13 Allu I Bangkala Subdistrik Jeneponto Regency by Jeopardy Games.The design of the study used classroom action research.The procedure of the research was done through some steps they were: planing, actuating, observation, and reflection. The data of the study were the research process and the result of the action that were gained from the result of observation, interview, anecdotal notes, documentation, and recording process. The result of the study showed that the tes in cucle I, there were 9 students or $36 \%$ got score $\leq 65$ and were 16 students or $64 \%$ categorized matery that got score $\geq 65$. The tes in cycle II, there were 4 students or $16 \%$ got score $\leq 65$ and were 21 students or $84 \%$ categorized matery that got score $\geq$ 65. The Implemen-tation of Jeopardy Games were able to improve the students attitude during the implementation of the classroom action research in cycle I and cycle II. To Improve the ability of the student to make question sentence, the teacher should be able to apply Jeopardy Games as one alternative in learning Indonesian.
\end{abstract}

Keyword:Imrovement,Abilitiy,Question Sentence,Jeopardy Games 


\section{PENDAHULUAN}

Pada dasarnya pembelajaran
bahasa Indonesia khususnya
pembelajaran keterampilan berbahasa
merupakan pembelajaran yang variatif
dan sangat menyenangkan dipelajari.

Hal ini disebabkan banyaknya wahana, sarana, alat dan lingkungan sekitar yang dapat dijadikan sebagai sumber belajar. Melalui pembelajaran keterampilan berbahasa yang kreatif dan inovatif, dapat meningkatkan motivasi belajar siswa sehingga secara tidak langsung dapat memberikan pengalaman baru kepada siswa untuk memahami, mengkaji, mengeksplorasi dan menganalisis materi pembelajaran. Siswa memiliki banyak kesempatan untuk dapat mengungkapkan gagasangagasannya berdasarkan pengalaman yang diperoleh di lapangan, baik secara lisan maupun tertulis.

Kita tidak dapat memungkiri bahwa sampai saat ini proses pembelajaran di sekolah pada umumnya dan pembelajaran bahasa Indonesia pada khususnya masih cenderung berpusat pada guru. Guru menyampaikan materi pelajaran dan siswa dituntut untuk menghafal semua pengetahuan. Pembelajaran yang lebih berorientasi pada penguasaan materi. Pembelajaran seperti ini memang terbukti berhasil dalam membekali anak memecahkan masalah dalam kehidupan jangka pendek. Namun yang diharapkan adalah pembelajaran yang berbasis PAIKEM. Dalam PAIKEM, digunakan prinsip-prinsip pembelajaran yang berbasis kompetensi adalah pembelajaran yang dilakukan dengan orientasi pencapaian kompetensi peserta didik, sehingga muara akhir hasil pembelajaran meningkatkan kompetensi peserta didik yang dapat diukur dalam pola sikap, pengetahuan, dan keterampilannya. Dalam Permendiknas No.41 Tahun 2007 tentang standar proses juga diamanatkan bahwa dalam kegiatan inti pembelajaran harus dilakukan secara interaktif, inspiratif, menyenangkan, menantang memotivasi peserta didik untuk berpartisipasi aktif, serta memberi ruang yang cukup bagi prakarsa, kreativitas, dan kemandirian sesuai dengan bakat, minat dan perkembangan fisik dan psikologis peserta didik.

Motode pengajaran bahasa Indonesia yang digunakaan di kelas V SDN No.13 Allu I Kecamatan Bangkala Kabupaten Jeneponto, selama ini cenderung menggunakan model lama yang memadukan metode ceramah, tanya-jawab dan penugasan, pada hal banyak model pembelajaran yang dapat diterapkan misalnya: Model kooperatif type Jiqsaw, Picture and Picture, Numbered Heads Together, Team Gemes Tournament ( TGT), dan Games Jeopardy.

Hal ini menjadi sumber inspirasi peneliti untuk menerapkan model pembelajaran yang menantang dan menyenangkan yang disesuaikan dengan situasi, kondisi dan minat peserta didik. Kalau selama ini siswa SD Negeri No.13 Allu Kecamatan Bangkala Kabupaten Jeneponto terbiasa menjawab pertanyaan dari dari bacaan yang baru saja disimak atau dibaca. Bagaimana kalau kita balik , siswa membuat pertanyaan berdasarkan jawaban yang ada, ini baru disebut pembelajaran yang menantang. Kalau selama ini siswa senang dan menghabiskan waktunya bermain games di rumah atau di tempat-tempat rental play station, bagaimana kalau 
diciptakan suasana pembelajaran games?

Efek model games ini mampu memberikan kondisi yang lebih rileks yang dirasakan siswa ketika belajar. Dengan kondisi ini, siswa tidak akan mengalami kelelahan belajar karena materi yang disajikan dalam model games ini adalah bentuk permaianan seperti halnya games yang banyak ditemui di rental -rental sekarang ini, Darmawan ( 2011:192 ).

Kenyakinan peneliti akan keberhasilan dalam perencanaan, pelaksanan dan penilaian penerapan Model Games Jeopardy dalam meningkatkan kemampuan siswa membuat kalimat tanya pada siswa kelas V SD Negeri No.13 Allu I Kecamatan Bangkala Kabupaten Jeneponto, didukung oleh penelitian, Nurhayati Sudding (2011:76) menyimpulkan bahwa penerapan Model pembelajaran Synectics dapat meningkatkan kemampuan menulis kalimat sederhana siswa kelas IV SD Inpres Pude Kabupaten Bone. Walaupun Model Pembelajaran yang diterapkan tidak persis sama tetapi setidaknya model Synectics dan Model Games Jeopardy merupakan model inovasi yang banyak memberikan kontribusi dan menciptakan pembelajaran yang menantang dan menyenangkan yang akan bermuara pada peningkatan hasil belajar bahasa Indonesia utamanya dalam membuat kalimat sederhana atau kalimat tanya, Bodrogini, dkk (2007).

Model

Games Jeopardy tergolong baru dan tidak banyak literatur atau buku model-model pembelajaran yang membahas model tersebut, tetapi telah diterapkan dibeberapa sekolah binaan DBE 2 pada program Developing Active Learning
With ICT (DALI), dienam propinsi di Indonesia tetapi di Amerika Serikat dan Kanada Games ini sangat populer.

\section{KAJIAN PUSTAKA}

Jika dilihat dari segi ketatabahasaan, maka kalimat diartikan sebagai bagian dari ujaran atau teks yang memiliki makna yang utuh. Hal ini sejalan dengan pendapat Muslich (1990:115) yang menyatakan bahwa kalimat adalah bagian terkecil ujaran atau teks (wacana) yang mengungkapkan pikiran dan perasaan yang utuh secara ketatabahasaan. Pendapat yang terakhir ini menitik beratkan pengertian kalimat pada jenis bahasa tulis.

Alisjahbana (1983:71) melihat kalimat dari aspek komunikasi, dinyatakan bahwa kalimat adalah satuan bentuk bahasa yang terkecil yang mengungkapkan suatu susunan pikiran yang lengkap sehingga komunikasi antara orang yang mengucapkan atau menuliskan kalimat terjalin dengan orang yang mendengar atau membacanya.

\section{a. Pengertian Kalimat tanya.}

Kalimat tanya disebut juga kalimat introgatif. Kalimat tanya adalah kalimat yang isinya menanyakan sesuatu atau seseorang. Jika orang ingin mengetahui jawaban terhadap suatu masalah atau keadaan, maka ia menanyakan-nya dan kalimat yang dipakai adalah kalimat tanya.

Kalimat tanya dapat dibentuk dengan cara menambah kata apa ( kah). Sebagai contoh kalimat berita dia akan datang dapat diubah menjadi kalimat tanya dengan menambahkan apakah, sehingga menjadi Apakah dia akan datang? Cara lain dengan ialah mengubah intonasi kalimat. Misalnya kalimat diucapkan menjadi Dia akan 
datang? Cara-cara lain untuk membentuk kalimat tanya ialah dengan membalikkan urutan kata, memakai kata bukan atau tidak, dan memakai kata tanya, Cahyono (1994:183).

Kalimat tanya adalah kalimat yang isinya menanyakan sesuatu, seseorang, keadaan atau masalah. Kalimat ini ditandai dengan pola intonasi tanya yang dalam bahasa tulis ditandai dengan tanda tanya (?)

\section{b. Ciri Kalimat Tanya}

Kalimat tanya memiliki ciri sebagai berikut :

1. Intonasi yang digunakan adalah intonasi tanya.

2. Sering menggunakan kata tanya.

3. Dapat pula menggunakan partikel tanya-kah.

\section{METODE}

Penelitian ini menggunakan rancangan penelitian tindakan kelas. Penelitian tindakan kelas ini bertujuan memecahkan masalah yang bersumber dari proses pembelajaran menulis kalimat tanya yang dilaksanakan

Tabel 4.1 Hasil Tes Belajar Siklus I

\begin{tabular}{|c|c|c|c|}
\hline Rentang Nilai & Frekuensi & Persentase & Kategori \\
\hline $0-34$ & 2 & $8 \%$ & Sangat rendah \\
\hline $35-54$ & 2 & $8 \%$ & Rendah \\
\hline $55-64$ & 5 & $20 \%$ & Sedang \\
\hline $65-84$ & 12 & $48 \%$ & Tinggi \\
\hline $85-100$ & 4 & $16 \%$ & Sangat Tinggi \\
\hline
\end{tabular}

Tabel 4.1 Hasil Tes Belajar Siklus I

Berdasarkan tabel 4.1 menunjukan bahwa hasil belajar siswa kelas $\mathrm{V}$ SDN No.13 Allu I Kecamatan Bangkala Kabupaten Jeneponto pada topik membuat kalimat tanya. Pembelajaran dengan menggunakan Model Games Jeopardy hasilnya dapat diuraikan bahwa dari 25 orang siswa dikelas terteliti. Arikunto dkk. ( 2010) menyatakan bahwa,“ penelitian tindakan kelas merupakan suatu bentuk penelitian bersifat reflektif dengan melakukan tindakan-tindakan tertentu agar dapat memperbaiki dan meningkatkan praktik-praktik pembelajaran di kelas dengan profesional. Hal ini sesuai dengan karakteristik penelitian tindakan kelas, yaitu bersifat kolaboratif, berfokus dengan problem praktis, penekanan pada pengembangan profesional, dan memerlukan adanya struktur proyek yang memungkinkan partisipan untuk berkomunikasi."

\section{HASIL}

\section{a. Siklus I}

\section{Analisis Hasil Tes Belajar}

Hasil tes pada siklus I yang merupakan data awal penelitian dalam menerapkan Model Games Jeopardy dalam meningkatkan kemampuan siswa membuat kalimat tanya. Hasil tes dapat dilihat pada tabel berikut. yang mengikuti tes siklus I pada siswa kelas V SD Negeri No.13 Allu I, terdapat 16 orang atau $64 \%$ siswa yang tuntas,tetapi mencapai standar Kriteria Ketuntasan Minimal (KKM) yaitu 80\% siswa yang memperoleh nilai $\geq 65$. 
Grafik 4.1 Hasil Tes Belajar Siklus I

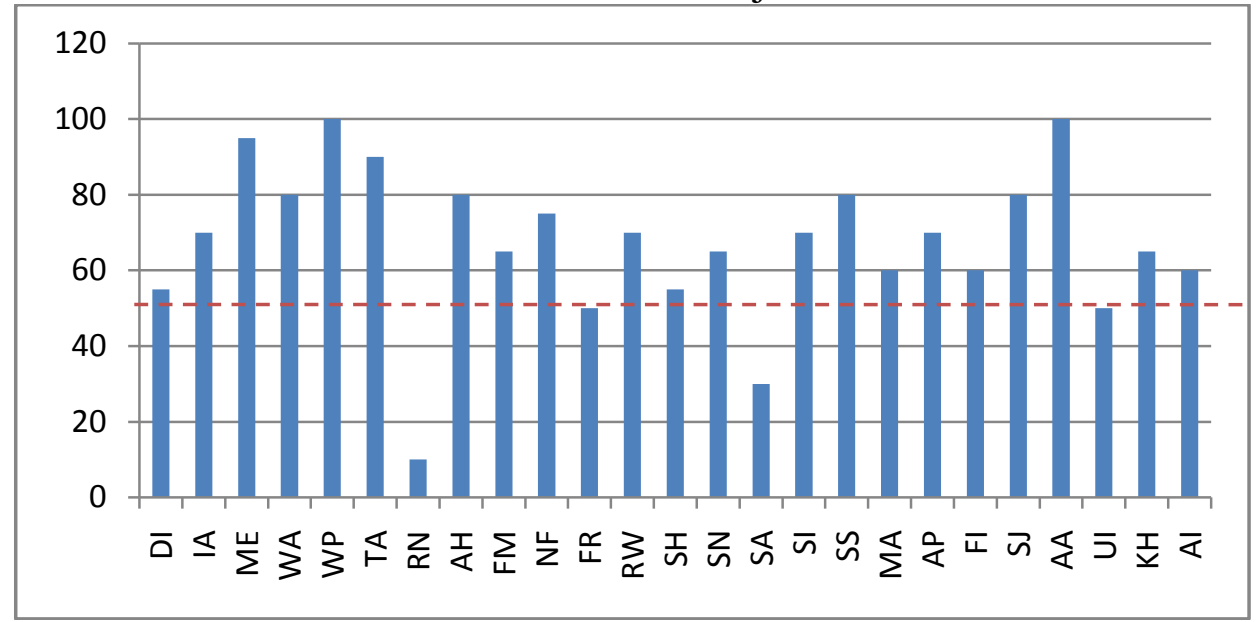

Grafik 4.1 Hasil Tes Belajar Siklus I

Berdasarkan Grafik 4.1 Hasil tes belajar siswa menunjukkan bahwa masih terdapat 9 orang atau $36 \%$ mendapat nilai $\leq 65$ dan 16 orang atau $64 \%$ siswa mendapat nilai $\geq 65$, ini berarti bahwa pada siklus I standar kriteria ketuntasan belum tercapai yaitu 20 orang atau $80 \%$ siswa mendapat nilai $\geq 65$.

Tabel 4.2 Distribusi Frekuensi Hasil Observasi Aktifitas Belajar Siswa Siklus I

\begin{tabular}{|c|c|c|c|c|c|c|}
\hline \multirow{2}{*}{ Kriteria penilaian } & \multicolumn{2}{|c|}{ Pertemuan I } & \multicolumn{2}{c|}{ Pertemuan II } & \multicolumn{2}{c|}{ Pertemuan III } \\
\cline { 2 - 7 } & $\begin{array}{l}\text { Fre- } \\
\text { kuensi }\end{array}$ & $\begin{array}{l}\text { Persen- } \\
\text { tase }\end{array}$ & $\begin{array}{l}\text { Fre- } \\
\text { kuensi }\end{array}$ & $\begin{array}{l}\text { Persen- } \\
\text { tase }\end{array}$ & $\begin{array}{l}\text { Fre- } \\
\text { kuensi }\end{array}$ & $\begin{array}{l}\text { Persen- } \\
\text { tase }\end{array}$ \\
\hline Keaktifan & 10 & $40 \%$ & 13 & $52 \%$ & 14 & $56 \%$ \\
\hline Kreatifitas & 7 & $28 \%$ & 11 & $44 \%$ & 15 & $60 \%$ \\
\hline Ketepatan & 8 & $32 \%$ & 12 & $48 \%$ & 14 & $56 \%$ \\
\hline
\end{tabular}

Tabel 4.2 Distribusi Frekuensi Hasil Observasi Aktifitas Belajar Siswa Siklus I

Berdasarkan data pada tabel 4.2 kereatifitas pada pertemuan pertama tersebut diatas diperoleh data dari $328 \%$, pertemuan kedua $44 \%$, pertemuan pada siklus I, untuk kriteria pertemuan ketiga $60 \%$. Untuk kriteria keaktipan pada pertemuan pertama ketepatan menulis kalimat tanya pada $40 \%$, pertemuan kedua $52 \%$, pada pertemuan pertama $32 \%$, pertemuan pertemuan ketiga $56 \%$. Untuk kriteria $48 \%$, dan pertemuan ketiga $56 \%$. Grafik 4.2 Distribusi Frekuensi Hasil Observasi Aktifitas Belajar Siswa Siklus I 


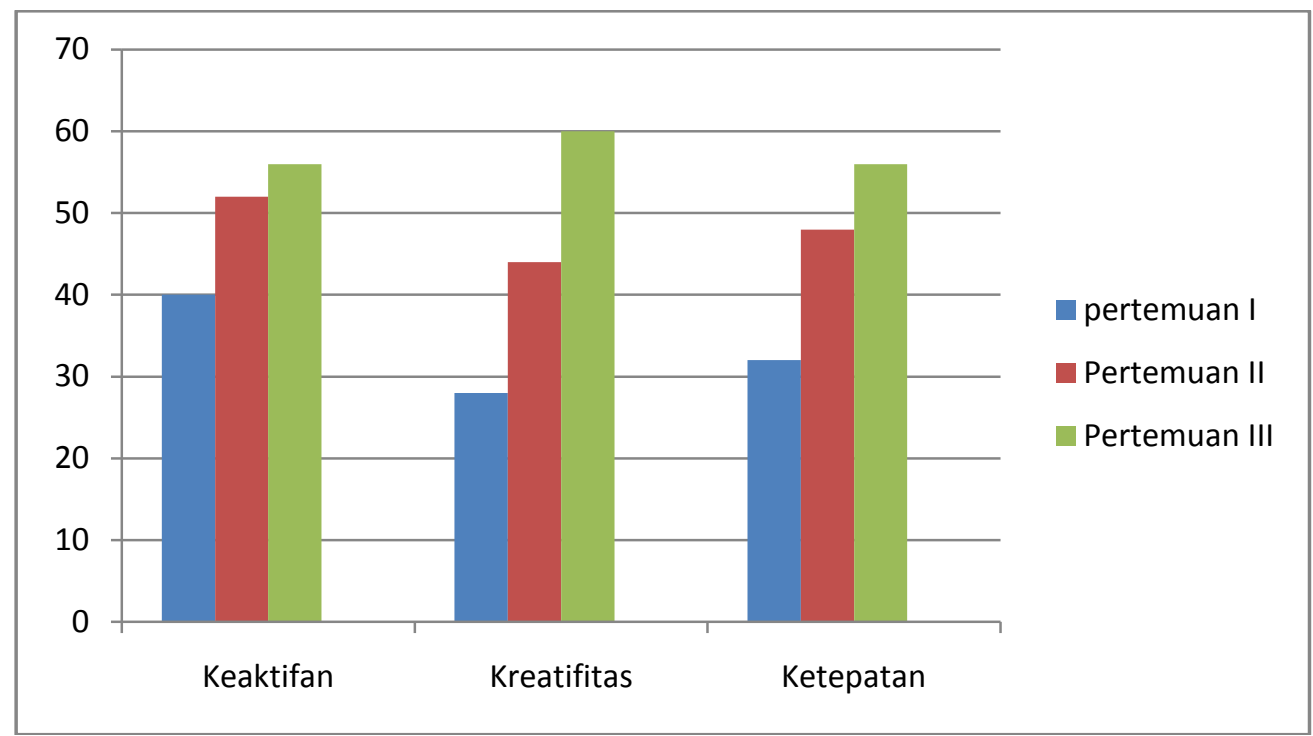

Grafik 4.2 Distribusi Frekuensi Hasil Observasi Aktifitas Belajar Siswa Siklus I

Berdasarkan grafik 4.2

Menunjukkan adanya peningkatan pada semua kriteria penilaian dari pertemuan pertama, kedua, dan ketiga. Pada kriteria keaktipan dari pertemuan pertama ke pertemuan kedua ada peningkatan $12 \%$,dari pertemuan kedua ke pertemuan ketiga ada peningkatan $4 \%$. Pada kriteria kreatifitas dari pertemuan pertama ke pertemuan kedua ada peningkatan $16 \%$ demikian pula pada pertemuan kedua ke pertemua ketiga ada peningkatan $16 \%$.Pada Kriteria ketepatan dari pertemuan pertama ke pertemuan kedua ada peningkatan $16 \%$, pada pertemuan ketiga ada peningkatan $8 \%$. Secara keseluruhan untuk semua kriteria terjadi peningkatan disetiap pertemuan namun demikian peningkatannya belum maksimal.

\section{Hasil Wawancara}

Selain lembar observasi peneliti melakukan wawancara dengan siswa untuk memperoleh informasi bagaimana respon siswa terhadap pembelajaran membuat kalimat tanya dengan menggunakan Model GamesJeopardy. Obyek wawancara adalah guru/kolaborasi dan dua orang siswa yang dipilih dari dua kelompok yang berbeda satu dari kelompok yang menjadi pemenang pada Games Jeopardy dan siswa kedua diambil dari siswa yang kalah dalam permainan Games Jeopardy.

Berdasarkan hasil wawancara dengan guru/kolaborasi yang dilaksanakan pada akhir siklus I, beliau mengemukan bahwa pembelajaran dengan model Games Jeopardy sangat berbeda dengan pembelajaran yang sering mereka laksanakan, hal ini terlihat dari antusias siswa dalam mengikuti pelajaran, pada akhir pelajaran selalu dilakukan refleksi semua siswa mengaku sangat senang bahkan ada yang bertanya," Kapan kita main games Jeopardy lagi bu?

Menurut siswa yang dipilih dari kelompok pemenang menjelaskan bahwa secara kebutulan dalam pemilihan anggota kelompok yang dilakukan secara acak mereka bertemu dengan teman teman yang mudah diajak bekerjasama, sehingga dengan mudah mereka merumuskan pertanyaan berdasarkan jawaban 
yang sudah ada, disamping itu isi bahan bacaan yang di bagikan harus dipahami dan yang tidak kalah penting adalah harus memahami penggunaan kata tanya.

Menurut siswa yang dipilih dari kelompok yang kalah dalam permainan mereka mengaku sangat senang dengan pembelajaran membuat kalimat tanya melalui Games Jeopardy, waktu ditanya mengapa kelompoknya kalah dalam permaian, mereka mengaku bahwa dalam mereka belum bisa membedakan penggunaan kata "bagaimana" dengan "mengapa" itulah yang menyebabkan kelompak salah dalam merumuskan pertanyaan, tetapi dengan kesalahan itu mereka menjadi mengerti. Disamping itu mereka mengeluh anggota kelompok tidak melaksanakan perannya dengan baik.

\section{b. Siklus II}

\section{Analisis Hasil Tes Belajar}

Hasil tes yang dilaksanakan pada akhir siklus II dapat kita lihat pada tabel hasil tes berikut .

Tabel 4.3 Hasil Tes Belajar Siklus II

\begin{tabular}{|c|c|c|c|}
\hline Rentang Nilai & Frekuensi & Persentase & Kategori \\
\hline $0-34$ & 0 & $0 \%$ & Sangat rendah \\
\hline $35-54$ & 0 & $0 \%$ & Rendah \\
\hline $55-64$ & 4 & $16 \%$ & Sedang \\
\hline $65-84$ & 11 & $44 \%$ & Tinggi \\
\hline $85-100$ & 10 & $40 \%$ & Sangat Tinggi \\
\hline
\end{tabular}

Tabel 4.3 Hasil Tes Belajar Siklus II

Berdasarkan hasil tes pada tabel memperoleh nilai sedang dengan hasil tes pembelajaran pada siklus II rentang nilai 55-64, tidak ada siswa menunjukan bahwa dari 25 Orang yang memperoleh nilai rendah dengan siswa yang mengikuti tes siklus II rentang nilai 35-54 dan tidak ada siswa tercatat 10 orang atau $40 \%$ siswa yang yang memperoleh nilai sangat rendah memperoleh nilai sangat tinggi dengan dengan rentang nilai $0-34$. Berikut rentang nilai 85- 100, 11 atau $44 \%$ ini disajikan hasil tes siklus II dalam yang memperoleh nilai tinggi dengan bentuk grafik. rentang nilai $65-84,4$ atau $16 \%$ yang

Grafik Hasil Tes Belajar Siklus II

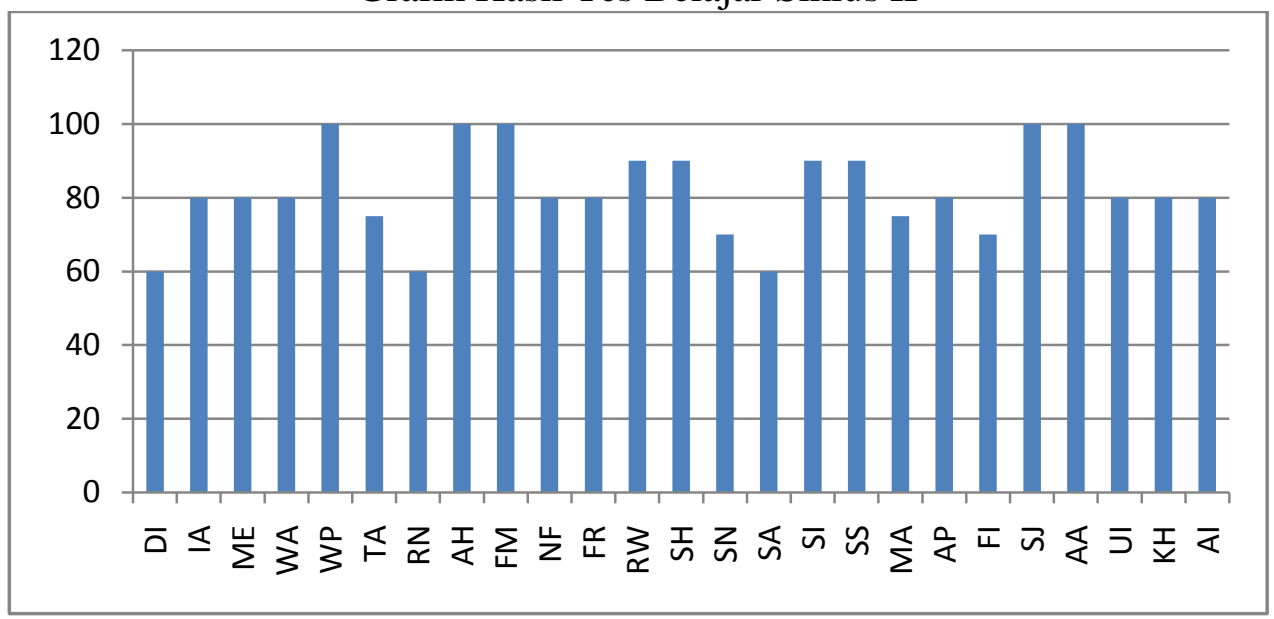


Grafik 4.3 Hasil Tes Belajar Siklus II

Dari data tersebut terdapat KKM . Maka model Gomes Jeopardy 21 atau $84 \%$ siswa yang berada pada mampu meningkatkan kemampuan kategori tuntas dengan nilai $\geq 65$ dan membuat kalimat tanya siswa kelas $\mathrm{V}$ hanya 4 atau $16 \%$ siswa yang SDN No.13 Allu I Kecamatan memperoleh nilai di bawah standar Bangkala Kabupaten Jeneponto.

\section{Analisis Hasil Observasi Aktifitas}

Siswa

Data tingkat aktifitas siswa yang Berikut ini akan dipaparkan deskrifsi diperoleh melalui pengamatan pada aktifitas siswa pada siklus II pada tabel setiap pertemuan disetiap siklus. 4.4 berikut!

Tabel 4.4 Distribusi Frekuensi Hasil Observasi Aktifitas Belajar Siswa Siklus II

\begin{tabular}{|c|c|c|c|c|c|c|}
\hline \multirow{2}{*}{ Kriteria penilaian } & \multicolumn{2}{|c|}{ Pertemuan I } & \multicolumn{2}{c|}{ Pertemuan II } & \multicolumn{2}{c|}{ Pertemuan II } \\
\cline { 2 - 7 } & $\begin{array}{l}\text { Fre- } \\
\text { kuensi }\end{array}$ & $\begin{array}{l}\text { Persen- } \\
\text { tase }\end{array}$ & $\begin{array}{l}\text { Fre- } \\
\text { kuensi }\end{array}$ & $\begin{array}{l}\text { Persen- } \\
\text { tase }\end{array}$ & $\begin{array}{l}\text { Fre- } \\
\text { kuensi }\end{array}$ & $\begin{array}{l}\text { Persen- } \\
\text { tase }\end{array}$ \\
\hline Keaktifan & 15 & $60 \%$ & 17 & $68 \%$ & 23 & $92 \%$ \\
\hline Kreatifitas & 17 & $68 \%$ & 18 & $72 \%$ & 21 & $84 \%$ \\
\hline Ketepatan & 18 & $72 \%$ & 20 & $80 \%$ & 23 & $92 \%$ \\
\hline
\end{tabular}

Tabel 4.4 Distribusi Frekuensi Hasil Observasi Aktifitas Belajar Siswa Siklus II

Berdasarkan data pada tabel 4.4 92\%.Untuk kriteria kreatifitas pada tersebut diatas diperoleh data dari tiga pertemuan I - III 17\%-84\%.Untuk pertemuan pada siklus II, untuk kriteria kriteria ketepatan menulis kalimat keaktipan pada pertemuan I - III 60\%- tanya pertemuan I - III 18\%-92\%. Grafik 4.4 Distribusi Frekuensi Hasil Observasi Aktifitas Belajar Siswa Siklus II

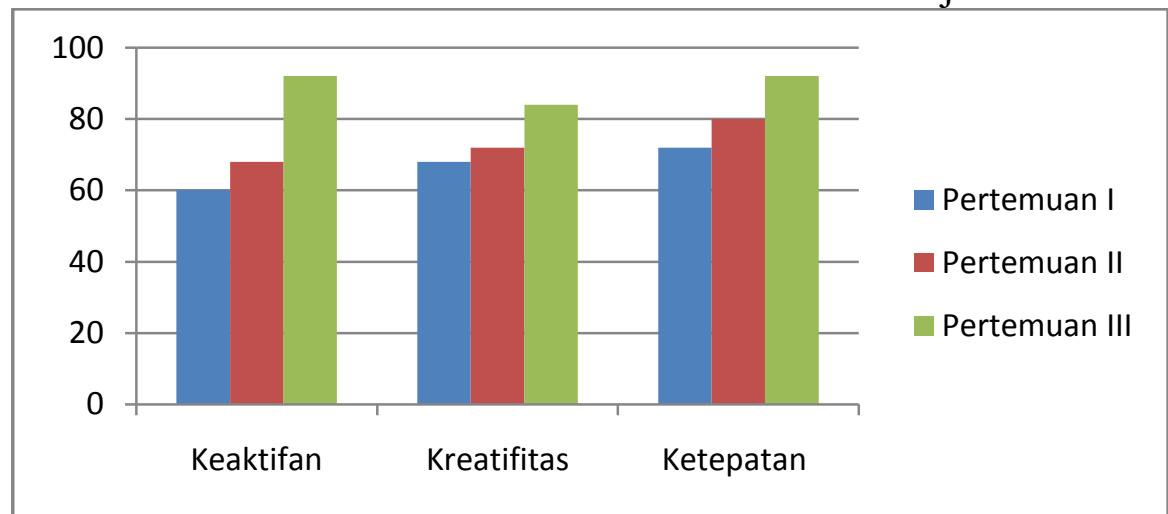

Grafik 4.4 Distribusi Frekuensi Hasil Observasi Aktifitas Belajar Siswa Siklus II

Berdasarkan grafik 4.4 Menunjukkan adanya peningkatan pada semua kriteria penilaian dari pertemuan pertama, kedua, dan ketiga. Pada kriteria keaktipan dari pertemuan pertama ke pertemuan kedua ada 
peningkatan $8 \%$,dari pertemuan kedua ke pertemuan ketiga ada peningkatan 24\%. Pada kriteria kreatifitas dari pertemuan pertama ke pertemuan kedua ada peningkatan $4 \%$ demikian pula pada pertemuan kedua ke pertemua ketiga ada peningkatan $12 \%$ .Pada Kriteria ketepatan dari pertemuan pertama ke pertemuan kedua ada peningkatan $8 \%$, pada pertemuan ketiga ada peningkatan $12 \%$.Secara keseluruhan untuk semua kriteria terjadi peningkatan dan peningkatannya sudah memenuhi kriteria ketuntasan $\geq 80$ untuk semua kriteria.

\section{Hasil Wawancara}

Pada siklus II peneliti melakukan wawancara dengan siswa untuk melengkapi data penelitia tentang pembelajaran membuat kalimat tanya dengan menggunakan Model Games Jeopardy. Obyek wawancara masih tetap sama pada siklus I yaitu guru/kolaborasi dan dua orang siswa yang dipilih dari dua kelompok yang berbeda satu dari kelompok yang menjadi pemenang dan siswa kedua dari kelompok yang kalah dalam permainan Games Jeopardy .

Pertama akan diuraikan hasil wawancara dengan guru. Berdasarkan hasil wawancara dengan guru/kolaborasi yang dilaksanakan pada akhir siklus II, beliau mengemukan bahwa pembelajaran dengan model Games Jeopardy sangat menarik dan merupakan solusi dalam menghadapi permasalahan yang selama ini sering dialami seperti siswa mengantuk, kurang semangat, tidak berani mengemukakan pendapat, cenderung passif, sifat egoisme/monopoli bagi anak yang cerdas saja. Games Jeopardy hadir memberi solusi semua bisa teratasi dengan baik, anak yang pintar dan sering monopoli pembicaraan diberi peran sebagai pemikir, anak yang pintar tapi pendiam diberi peran sebagai pembicara, anak yang superaktif dan cenderung lemah dalam hal berpikir diberi peran sebagai penunjuk jari, anak yang kurang bergaul di beri peran memimpin yelyel. Selain itu menurut ibu guru/ kolaborasi Model Games Jeopardy menumbuhkan karakter siswa seperti, meningkatkan aktivitas, menciptakan koraborasi siswa, memupuk rasa tanggung jawab, menumbuhkan persaingan yang sehat, kejujuran dan kedisiplinan.

Menurut siswa yang dipilih dari kelompok pemenang maupun yang kalah menjelaskan bahwa Model Games Jeopardy sangat menarik dan menatang yang menarik dari permaian ini adalah pembelajaran ini menggunakan peralatan ICT, ada yelyel yang berfungsi sebagai penyemangat sehingga kita terus semangat serta menatang karena siswa harus merumuskan pertanyaan berdasarkan jawaban yang ada.

\section{PEMBAHASAN}

Penelitian tindakan kelas (class room action research-car) dilaksanakan selama dua siklus. Pada siklus I dan II peneliti melakukan kegiatan membuat kalimat tanya dengan menerapkan model Games Jeopardy. Menurut Susilo (2009), mengatakan bahwa kalimat tanya memiliki ciri yaitu memakai kata tanya dan intonasi tanya, tetapi bila kalimat tanya mengandung kata tanya kita boleh memilih antara: menggunakan intonasi tanya, atau boleh juga mempergunakan intonasi berita. Games Jeopardy dengan keunikan dalam format permainannya, yaitu peran 
pertanyaan dan jawaban terbalik, pertanyaan adalah jawaban dan jawaban adalah pertanyaan, menjadikan model Games Jeopardy sebagai solusi mengatasi kesulitan siswa membuat kalimat tanya dengan menggunakan kata tanya yang tepat.

Penerapan Model Games Jeopardy dalam membuat kalimat tanya dimulai dengan kegiatan awal guru menyampaikan tujuan pembelajaran dan langkah-langkah kegiatan secara singkat hal ini bertujuan agar siswa sebagai subyek belajar memahami apa yang akan dilakukan dan kemana arah yang akan dituju, selanjutnya guru menjelaskan penggunaan kata tanya berdasarkan fungsinya misalnya, "kata apa", digunakan untuk menanyakan hal atau benda, "kata siapa", digunakan untuk menanyakan orang demikian seterusnya. Setelah itu siswa dibagi menjadi empat kelompok, karena jumlah siswa kelas V SDN No.13 Allu I sebanyak 25 orang maka tiga kelompok beranggotakan 6 orang dan satu kelompok beranggotakan 7 orang. Kelas dengan jumlah siswa sebanyak ini sangat efektif dan pengajaran bahasa hal ini sejalan dengan pendapat, Rahman Rahim (2010:143) yang mengatakan bahwa proses belajar bahasa akan lebih efektif bila ruangan kelas yang digunakan cukup luas dan jumlah siswanya antara 20-25 orang. Selanjutnya guru membagikan bahan bacaan pada setiap kelompok, bahan bacaan ini dibaca secara bergiliran oleh masing-masing perwakilan kelompok, peran guru dalam hal ini adalah mengoreksi jika ada kesalah dari segi lafal, intonasi, dan penggunaan tanda baca terutama intonasi kalimat tanya. Sebelum pemainan Games Jeopardy dimulai terlebih dahulu membagi kartu peran tujuannya supaya semua anggota kelompok punya peran masing-masing. Berdasarkan hasil observasi pada pertemuan pertama sampai pertemuan ketiga siklus I keaktifan siswa sekitar $40 \%$ - 56\%, kreatifitas $28 \%$ - 60\%, dan ketepatan $32 \%-56 \%$.

Pelaksanaan pembelajaran pada siklus II pada umumnya sama dengan kegiatan pada siklus I, namun ada bagian yang perlu diperbaiki, dibagian perencanaan , Rencana Pelaksanaan Pembelajaran (RPP) perlu ada perbaikan pada langkah-langkah pembelajaran yakni perlu ada pergantian urutan kegiataan. Pada bagian pelaksanaan perlu ada peningkatan keterampilan guru/kolaborasi dalam memainkan Model Games Jeopardy, berdasarkan hasil observasi pada siklus I ditemukan kesalahan teknis yang dilakukan oleh guru/kolaborasi dalam menggunkan games. Selain itu guru perlu mempertegas pembagian peran masingmasing siswa dalam kelompok.Segala upaya yang dilakukan secara maksimal untuk meningkatkan kemampuan membuat kalimat tanya menunjukkan hasil yang menggembirakan, semua kriteria penilaian: keaktifan, kreatifitas, dan ketepatan membuat kalimat tanya mengalami peningkatan, yaitu pada kisaran $80 \%-92 \%$.

Berdasarkan tabel hasil tes siklus I, dapat diketahui bahwa kemampuan membuat kalimat tanya melalui model games Jeopardy siswa kelas V SDN No.13 Allu I Kecamatan Bangkala Kabupaten Jeneponto yang menjadi subyek penelitian, perolehan skor atau bobot dalam penelitian ini mengalami peningkatan secara signifikan. Hasil belajar siswa pada siklus I yaitu 16 orang atau $64 \%$ siswa memperoleh nilai 65 . 
Pada siklus II, tercatat 21 orang siswa atau $84 \%$ siswa memperoleh nilai $\mathrm{KKM} \geq 65$ dalam interval persentase tingkat penguasaan siswa, skor tersebut termasuk kategori tinggi dan sudah mencapai indikator ketuntasan belajar yang ditetapkan yakni $80 \%$ atau lebih siswa yang menperoleh nilai $K K M \geq 65$. Sehingga penambahan siklus ke-n tidak dilaksanakan lagi. Oleh karena itu, pembelajaran membuat kalimat tanya melalui Model Games Jeopardy, siswa kelas V SDN No.13 Allu I Kecamatan Bangkala Kabupaten Jeneponto mengalami peningkatan.

\section{SIMPULAN}

Dari hasil penelitian tindakan kelas ini dapat simpulkan bahwa pening-katan kemampuan membuat kalimat tanya melalui Model Games Jeopardy siswa kelas V SDN No.13 Allu I Kecamatan Bangkala kabupaten Jeneponto dilakukan melalui beberapa tahapan antara lain:

1. Perencanaan pembelajaran membuat kalimat tanya melalui Model Games Jeopardy siswa kelas V SDN No.13 Allu I Kecamatan Bangkala Kabupaten Jeneponto yang disusun secara kolaborasi dengan guru kelas $\mathrm{V}$ memuat: standar kompetensi, kompetensi dasar, indikator, tujuan pembelajaran, materi pembelajaran, metode pembelajaran, langkah-langkah pembelajaran, alokasi waktu, sumber pembelajaran, alat serta penilaian. Semua komponen tersebut terdapat dalam rencana pembelajaran pada siklus I dan II. Berdasarkan hasil refleksi pada akhir siklus I maka pada siklus II dilakukan perbaikan pada komponen tertentu yaitu pada komponen penilaian yang dinilai kurang relevan dengan indikator pencapaian tujuan pembelajaran dan beberapa penyem-purnaan Story Board Games Jeopardy serta peralatan pendukung lainnya. Perencanan merupakan kunci utama keberhasilan sebuah pembelajaran jika perencanaan dilakukan dengan akan mempengaruhi keberhasilan pelaksanaan pembelajaran dan penilaian.

2. Pelaksanaan pembelajaran menyusun kalimat tanya melalui Games Jeopardy siswa kelas V SDN No.13 Allu I Kecamatan Bangkala Kabupaten Jeneponto di laksanakan selama dua siklus setiap siklus tiga kali pertemuan. Keberhasilan pelaksanaan pembelajaran membuat kalimat tanya melalui games Jeopardy tergambar data hasil belajar, data hasil observasi aktifitas guru dan siswa,dan hasil wawancara. Data tersebut menggambarkan beberapa keunggulan Games Jeopardy antara lain: 1) Permainannya meningkatkan hasil belajar siswa, 2) meningkatkan aktivitas belajar yaitu, keaktifan, kreatifitas, dan ketepatan. Keterangan tersebut dibuktikan oleh data hasil observasi dari tiga kriteria penilaian yaitu: keaktifan, kreatifitas dan ketepatan pada siklus I berada pada kisaran 28\% - 60\%, pada siklus II semua kriteria mengalami peningkatan yakni berada pada kisaran $80 \%-92 \%$.

3. Penilaian pembelajaran membuat kalimat tanya melalui Games Jeopardy siswa kelas V SDN No.13Allu I Kecamatan Bangkala Kabupaten Jeneponto terdiri dari dua, yaitu penilaian proses dan penilaian hasil pembelajaran. Pada siklus I dan II penilaian proses 
disusun dalam bentuk lembar observasi dan wawancara sedangkan penilaian hasil pembelajaran disusun dalam bentuk tes membuat kalimat tanya dengan menggunakan kata tanya yang tepat berdasarkan jawaban yang sudah ada yang dilaksanakan diakhir siklus. Data hasil tes siklus I menununjukkan bahwa dari 25 orang siswa yang ikut tes membuat kalimat tanya dengan menggunakan kata tanya yang tepat berdasarkan jawaban yang sudah ada tercatat 16 orang atau $64 \%$ yang termasuk dalam kategori tuntas yaitu memperoleh nilai sesuai dengan standar $\mathrm{KKM} \geq 65$. Pada siklus II hasil tes pembelajaran mengalami peningkatan yaitu dari 25 orang siswa yang ikut tes membuat kalimat tanya dengan menggunakan kata tanya yang tepat berdasarkan jawaban yang sudah ada tercatat 21 orang atau $84 \%$ yang termasuk kategori tuntas yaitu memperoleh nilai KKM $\geq 65$. Berdasarkan data tersebut dapat disimpulkan bahwa penggunaan model Games Jeopardy dapat

\section{DAFTAR PUSTAKA}

Alisjahbana,S.T. 1983. Tata Bahasa Baku Bahasa Indonesia. Jilid I. Jakarta : Dian Rakyat.

Arikunto,S,dkk .2010. Penelitian

Tindakan Kelas. Jakarta: Bumi Aksara.

Bodrogini, dkk. 2007. Pengembangan Pembelajaran Aktif dengan Teknologi dan Komunikasi .Jakarta : DBE 2

Cahyono.1994. Kristal-Kristal Ilmu Bahasa. Malang:Airlangga University Press. meningkatkan kemampuan membuat kalimat tanya siswa kelas V SDN No.13 Allu I Kecamatan Bangkala Kabupaten Jeneponto.

\section{SARAN}

Berdasarkan kesimpulan diatas, maka peneliti memberi saran sebagai berikut :

1. Model Games Jeoapardy dapat dikembangkan oleh rekan- rekan guru di SDN No.13 Allu I Kecamatan bangkala Kabupaten Jeneponto sebagai salah satu model pembelajaran alternatif dalam pembelajaran bahasa indonesia.

2. Bagi Guru/Kolaborasi dapat menjadi motivator dan tempat bertanya bagi rekan-rekan guru di SDN No.13 Allu I Kecamatan Bangkala Kabupaten Jeneponto, yang berminat menerapkan Model Games Jeopardy.

3. Bagi Kepala Sekolah SDN No.13 Allu I tetap memberi dukangan kepada rekan-rekan guru di SDN 1 Allu I untuk terus mengembangkan Model Games Jeopardy di Sekolahnya.

Darmawan,Deni. 2011.Teknologi Pembelajaran. Bandung: PT.Remaja Rosdakarya

Hamalik.1991. Proses Belajar Mengajar. Jakarta : Bumi Aksara.

Muslich,M.1990. Tata Bahasa Bahasa Baku Bahasa Indonesia. Malang: Yayasan Asah Asih Asuh.

Rahim. 2010. Bahasa dan Berbahasa. Makassar: Universitas Muhammadiyah Makassar. 
Sudding, 2011. Penerapan Metode

Sinectic dalam Meningkatkan

Kemampuan Menulis Kalimat

Sederhana Bahasa Indonesia

Siswa kelas IV SD Inpres 12

Pude Kabupaten Bone.PTK :

Kabupaten Bone. Tesis tidak

diterbitkan. Makassar: Program

PascaSarjanan Universitas

Muhammadiyah Makassar.
Susilo.2009. Ilmu Bahasa

Sintaksis.(online)(http:// www.

susilo.edi.setiawan.com)

diakses 30 April 2012). 